\title{
Databáze realizovaných kupních cen nemovitých věcí
}

\author{
Database of Completed the Purchase of Real Estate Prices
}

\author{
Tomáš Hudec \\ Znalecká kancelár̆, Brno
}

\begin{abstract}
ABSTRAKT
Článek se zabývá způsobem tvorby a uživáním databáze realizovaných kupních cen a nájmů nemovitých věcí. Databáze je vytvářena a užívána skupinou znalců a odhadců pracujících v oboru oceňování nemovitých věcí v různých oblastech, zejména pro banky, soudy, exekutorské úřady, finanční úřady a podobně. Databáze slouží jako pomůcka pro stanovení obvyklých cen a nájmů oceňovaných nemovitých věcí porovnávacím způsobem.
\end{abstract}

Kličová slova: databáze, nemovitá věc, obvyklá cena, porovnání.

\section{1. ÚVOD}

V současné době je při stanovování obvyklé ceny nemovitých věcí kladen velký důraz na porovnávací způsob ocenění. Při použití této metody stojí každý znalec před problémem, jakým způsobem vybrat vhodný statistický vzorek porovnávacích nemovitých věcí. K dispozici jsou tři základní možnosti výběru vhodných dat:

1. vlastní databáze realizovaných kupních cen (popř. pronájmů),

2. internetová a tištěná realitní inzerce nebo

3. externí databáze realizovaných kupních cen (popř. pronájmů).

V prvním případě je výhodou osobní znalost získaná prohlídkou a zaměřením daných nemovitých věcí. Nevýhoda je zřejmá a tou je značně omezený počet nemovitých věcí uložených ve vlastní databázi.

V druhém př́ípadě je situace opačná. Počet hledaných srovnávacích nemovitých věcí může být obrovský, avšak nevýhody plynoucí z takto získaných informací jsou mnohdy tak výrazné, že znamenají nutnost vyloučení takového vzorku z porovnání. Prvním negativem je skutečnost, že uvedená cena je pouze nabídková, tzv. vyvolávací a s velkou pravděpodobností bude nakonec dosaženo jiné kupní ceny. Spolehlivým vodítkem pro odhadnutí koeficientu redukce na pramen ceny nemůže být ani datum vložení inzerátu do realitní inzerce a jeho aktualizace, jelikož

\begin{abstract}
This article is concerned with the way of creating and using the database of realized purchase prices and rents of properties. The database is created and used by a group of experts and appraisers working in the domain of valuation of immovable properties in various spheres, especially for banks, courts, executor offices, tax offices, and so on. This database is used as a tool for determining common prices and rents of valued properties in a comparative manner.
\end{abstract}

Keywords: database, immovable property, common price, comparison.

řada prodejců původní inzerát stahuje z nabídky a opět jej vkládá zpět jako zcela novou nabídku. Samostatnou kapitolou by potom bylo posouzení objektivnosti a přesnosti jednotlivých informací popisujících nabízenou nemovitou věc. Výjimkou nejsou informace typu, že zastavěná plocha, podlahová plocha i celková plocha pozemku jsou shodně např. $200 \mathrm{~m}^{2}$. Textové informace obvykle vyzdvihují a zdůrazňují pouze (fiktivní) pozitiva a o negativech se nezmiňují. Z realitní inzerce obvykle není možné stanovit, jaké jsou podlahové plochy suterénu, podkroví nebo garáže tak, aby se celková podlahová plocha dala přepočítat na započitatelnou plochu požadovanou metodikami bank.

Ve třetím př́padě jsou, při vhodném způsobu tvorby a užívání databáze, spojeny výhody předchozích dvou popsaných způsobů a eliminovány jejich nevýhody. Počátky tohoto způsobu tvorby databáze spadají před rok 2010. V této době si kolegové znalci z Brna a okolí vyměňovali jedenkrát za čtvrtletí v rámci pravidelných schůzek konaných u Krajského soudu Brno informace o prodaných nemovitých věcech. Jednalo se o listiny s vytištěnými tabulkami různého tvaru a formátu a s různými informacemi podle zvyklostí toho kterého znalce. Autor tohoto článku použil tento neformální systém jako základ k vytvoření projektu jednotného elektronického způsobu sdílení informací o kupních cenách a sjednaných nájmech nemovitých věcí. 
Tento projekt byl vytvořen a prezentován na několika odborných semináŕích v roce 2010, za podpory Asociace znalců a odhadců, profesní obor stavebnictví a nemovitosti Morava. Od června do prosince 2010 procházel zkušebním testovacím provozem a v lednu 2011 byl zahájen standardní provoz v regionu Jihomoravského kraje. V současné době probíhá osmý rok standardního provozu. Následující část tohoto článku se zabývá právě tímto způsobem tvorby a užívání databáze, umístěné na vyhrazeném ftp serveru.

\section{2. Účel databáze a otázka mlčenlivosti znalce}

Databáze umožňuje znalcům a odhadcům sdílet on-line způsobem informace o realizovaných kupních cenách nemovitých věcí a nájmech včetně přesných popisných informací o těchto nemovitých věcech. Takto získané informace se pak dají využít pro ocenění nemovitých věcí a stanovení nájmů porovnávacím způsobem.

Systém je určen registrovaným členům z řad odborné veřejnosti, kteří dodržují smluvní podmínky užívání serveru, a to zejména:

- minimální množství uživatelem vložených dat během období jednoho čtvrtletí,

- pravdivost uváděných informací,

- ochrana osobních údajů,

- užívání informací získaných z tohoto serveru pouze pro vlastní odbornou činnost.

Zajištění ochrany osobních údajů a mlčenlivost znalce jsou ošetřeny tak, že informace uvedené v tabulkách neobsahují konkrétní údaje označující danou nemovitou věc a jejího vlastníka, jako např. číslo popisné, číslo jednotky, parcelní číslo, jméno vlastníka a podobně. Nutno podotknout, že převažující část vkládaných tabulek se týká případů, kdy je prováděno ocenění formou odhadu obvyklé ceny pro banky, notáře apod. a nejedná se tedy o znalecký posudek. Na informace použité v tabulkách se nevztahuje zákon o znalcích a tlumočnících č. 36/1967 Sb. ve znění zákona č. 444/2011 Sb.

Použití tabulek s informacemi o nemovitých věcech je smluvně omezena pouze pro vlastní odbornou činnost uživatele databáze při oceňování nemovitých věcí a stanovení nájmů ve znaleckých posudcích a odhadech obvyklých cen.

\section{ZÁKLADNÍ PRAVIDLA PRO UŽíVÁNÍ DATABÁZE}

Užívání databáze, resp. zasílání vlastních dat a jejich stahování ze serveru funguje na principu registrovaného př́stupu na uzavřený znalecký ftp server prostřednictvím zřízeného osobního účtu $\mathrm{s}$ přidělenými př́istupovými údaji. Přístup $\mathrm{k}$ tomuto serveru je možný přes internetové připojení pomocí správce souborů, např̀. Total Commander (tzv. souborový manažer).

Server je rozdělen na dva základní adresáře. První adresár̆ má název nemovitosti_sklad a slouží uživatelům pro ukládání vlastních souborů formou zápisů do jednotných tabulek podle typu nemovité věci. Provozovatel serveru provádí průběžně kontrolu a administraci těchto uložených tabulek a následně je přemist'uje do prř́slušných podadresářò $\mathrm{v}$ druhém základním adresáři nazvaném nemovitosti_data.
Uživatelé databáze mají možnost kdykoliv stahovat $\mathrm{z}$ adresáře nemovitosti_data požadované informace. Pro vyhledávání konkrétních informací jako je typ nemovité věci, lokalita a časové období realizace kupní ceny se užívají dva základní způsoby. V první fázi zúžení výběru hledaných informací se použije vyhledání př́slušného podadresáře tzv. prokliknutím do dané podadresářové úrovně. Např́íklad při požadavku vyhledání rodinných domů z roku 2017 umístěných v lokalitě Brno-město se provede prokliknutí do úrovně nemovitost_data/2017/01JM/Lok 1 BM/01 RD. Zde jsou uloženy soubory ve Wordu a PDF formátu vytvořené v jednotlivých měsících roku 2017 a pojmenované podle daných kritérií, např. RD_01JM_L1_17_01.doc. Název souboru označuje, že jsou v něm obsaženy tabulky se zrealizovanými kupními cenami rodinných domů, které byly uloženy do databáze v roce 2017 . Tyto domy se nacházejí v Jihomoravském kraji, v lokalitě $1=$ Brno-město a soubor vznikal a rozrůstal se v průběhu měsíce ledna $=01$. Ve chvíli, kdy začnou být tabulky ukládány do souborů s označením následujícího měsíce, je soubor s označením měsíce ledna, tedy 01 uzavřen a je k němu prriřazena kopie ve formátu PDF. To znamená, že od tohoto okamžiku již není nutné ze serveru opět stahovat soubor s tímto označením, ale pouze soubor s označením právě probíhajícího měsíce.

Druhým způsobem podrobnějšího hledání určité nemovité věci v jednotlivých souborech je selekce př́islušných konkrétních tabulek provedená pomocí stisku kombinace kláves $C t r l f$ ve Wordu nebo okno s označením hledat v Acrobatu. Zde se napíše hledané slovo, např. Lesná. Tento prŕíkaz umožní procházet pouze ty tabulky, ve kterých se nachází hledané slovo.

Rozdělení lokalit je provedeno podle jednotlivých krajů České republiky a v rámci krajů ještě na 2 až 3 lokality zahrnující jednotlivé okresy.

\section{JEDNOTNÁ METODIKA ZÁPISŮ}

Pro zapisování informací do tabulek vytvořených pro jednotlivé typy nemovitých věcí byla stanovena jednotná metodika zápisu popisných informací. Návrh vzhledu tabulek prošel během zkušebního provozu serveru vývojem na základě připomínek uživatelů. Po následné diskuzi na různých setkáních s účastníky zkušebního provozu byl při dotvoření grafického vzhledu a uspořádání tabulek kladen důraz zejména na jejich jednoduchost a přehlednost, a to při zachování obsahu se všemi podstatnými informacemi, které mohou ovlivňovat stanovení obvyklé ceny nemovité věci porovnávacím způsobem. V následujících letech byly doplněny drobné změny zohledňující metodické požadavky České bankovní asociace pro stanovení rozměrových parametrů budov, jednotek a pozemků $v$ rámci odhadů pro úvěrová rízení. Na obr. 1-3 jsou uvedeny př́klady tabulek pro 3 různé typy nemovitých věcí.

\section{POPIS VYPLŇOVÁNÍ JEDNOTLIVÝCH BUNĚK V TABULKÁCH PRO RODINNÉ DOMY}

V následujícím textu je popsán způsob vyplňování jednotlivých buněk v tabulkách určených pro popis rodinných domů. Buňky pro vyplňování $\mathrm{v}$ tabulkách určených pro byty a další typy nemovitých věcí jsou obdobné. 


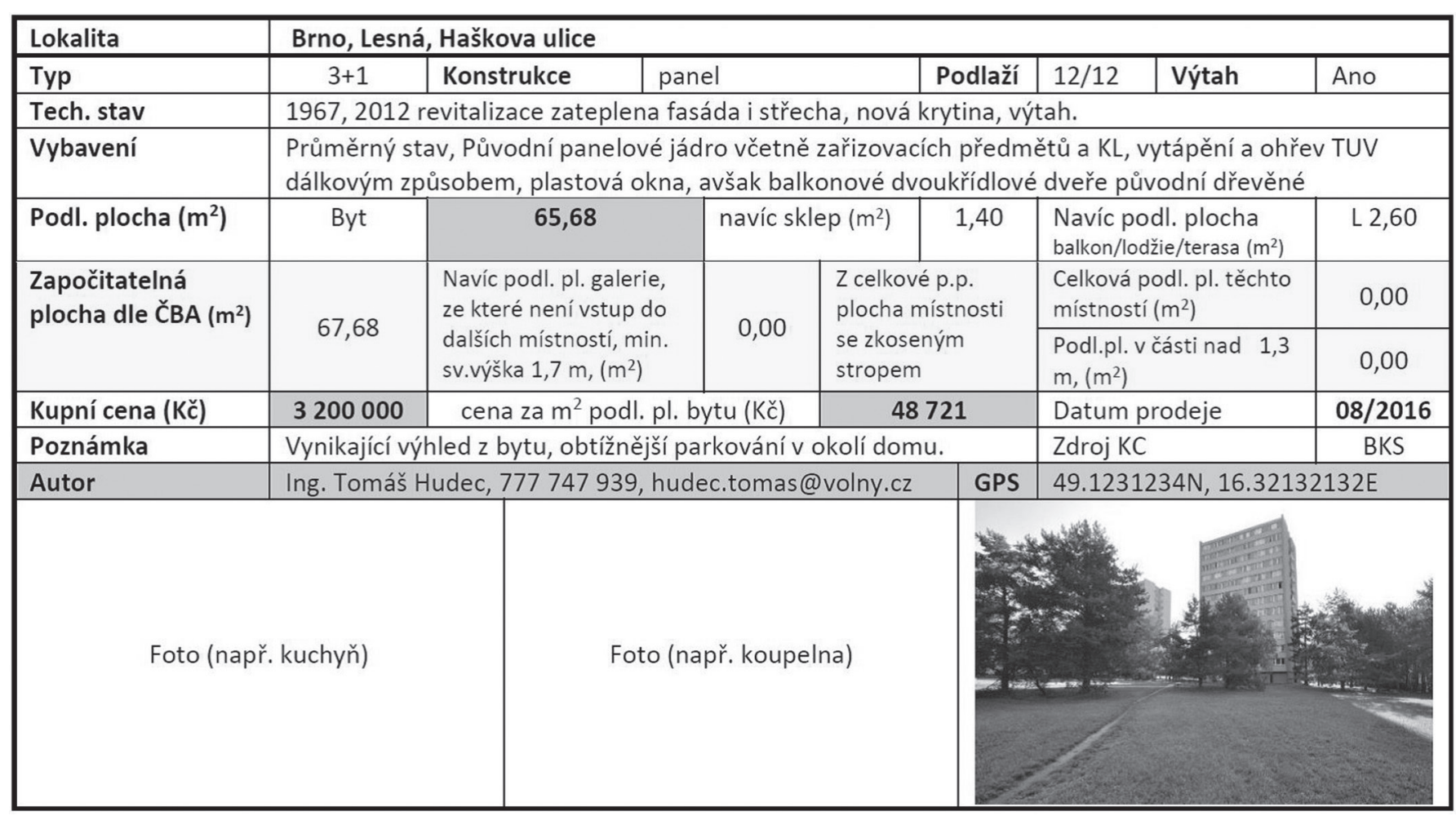

Obr. 1 Př́klady tabulky pro byty.

Fig. 1 Examples of a table for apartments.

\begin{tabular}{|c|c|c|c|c|c|c|c|c|c|c|c|}
\hline \multirow{2}{*}{ Lokalita } & \multicolumn{11}{|c|}{ Brno, Komín, ul. Hlavní, frekventovaná ulice } \\
\hline & \multicolumn{5}{|c|}{$1 \mathrm{PP} / 1 \mathrm{NP}$} & \multicolumn{2}{|l|}{ Typ } & \multicolumn{4}{|c|}{$5+1$, garáž } \\
\hline Tech. stav & \multicolumn{11}{|c|}{ Kolaudace v roce 1977. Pouze běžná údržba. Vlhkost zdiva v suterénu. } \\
\hline Vybavení & \multicolumn{11}{|c|}{$\begin{array}{l}\text { Standard 80. let. + krb v obývacím pokoji. Břizolitová fasáda, okna dřevěná zdvojená, vytápění a ohřev } \\
\text { TUV ústřední s kotlem na zemní plyn, podlahy vlýsky a keramická dlažba, plechová vana, kombi WC. }\end{array}$} \\
\hline Zastav. pl. RD (m²) & \multicolumn{2}{|c|}{76,50} & \multicolumn{4}{|c|}{ Podl. plocha celková $\left(\mathrm{m}^{2}\right)$} & 150,00 & \multicolumn{3}{|c|}{ Obest. prostor $\left(\mathrm{m}^{3}\right)$} & 710,00 \\
\hline $\begin{array}{l}Z \text { celkové p.p. } \\
\text { pl.sklepa }\left(m^{2}\right)\end{array}$ & 48,00 & \multicolumn{2}{|c|}{$\begin{array}{l}\text { z celkové p.p. } \\
\text { pl. garáže }\left(\mathrm{m}^{2}\right)\end{array}$} & 16,00 & \multicolumn{3}{|c|}{$\begin{array}{l}\text { z celkové p.p. plocha } \\
\text { průjezdu }\left(\mathrm{m}^{2}\right)\end{array}$} & 0,00 & \multicolumn{2}{|c|}{$\begin{array}{l}\text { Navíc podl. plocha } \\
\text { balkon/lodžie/terasa }\left(\mathrm{m}^{2}\right)\end{array}$} & L 10,00 \\
\hline \multirow[t]{2}{*}{$\begin{array}{l}\text { Započitatelná } \\
\text { plocha dle ČBA }\left(\mathrm{m}^{2}\right)\end{array}$} & \multirow[t]{2}{*}{115,00} & \multirow{2}{*}{\multicolumn{3}{|c|}{$\begin{array}{l}\text { Navíc podl. pl. galerie, ze } \\
\text { které není vstup do } \\
\text { dalších místností, min. } \\
\text { sv.výška } 1,7 \mathrm{~m},\left(\mathrm{~m}^{2}\right)\end{array}$}} & \multirow{2}{*}{\multicolumn{2}{|c|}{0,00}} & \multirow{2}{*}{\multicolumn{2}{|c|}{$\begin{array}{l}\text { Z celkové p.p. } \\
\text { plocha místnosti } \\
\text { se zkoseným } \\
\text { stropem }\left(\mathrm{m}^{2}\right)\end{array}$}} & \multicolumn{2}{|c|}{$\begin{array}{l}\text { Celková podl. pl. těchto } \\
\text { místností }\left(\mathrm{m}^{2}\right)\end{array}$} & 0,00 \\
\hline & & & & & & & & & \multicolumn{2}{|c|}{$\begin{array}{l}\text { Podl.pl. v části nad } 1,3 \\
m,\left(m^{2}\right)\end{array}$} & 0,00 \\
\hline Pozemek $\left(\mathrm{m}^{2}\right)$ & \multicolumn{2}{|r|}{400} & \multicolumn{2}{|c|}{ Napojení na sítě } & \multicolumn{4}{|c|}{ Voda, kanalizace, plyn, el. } & & & \\
\hline Příslušenství & \multicolumn{11}{|c|}{ Vedlejší stavba zděná - sklad nářadí - podl.pl. $20 \mathrm{~m}^{2}$, standardní venkovní úpravy } \\
\hline Kupní cena (Kč) & \multicolumn{2}{|c|}{5500000} & \multicolumn{4}{|c|}{ cena za m² celk. podl. plochy (Kč) } & \multicolumn{2}{|c|}{36667} & Datum prodeje & \multicolumn{2}{|c|}{$05 / 2016$} \\
\hline Poznámka & \multicolumn{8}{|c|}{$\begin{array}{l}\text { Rodinný dům je zasazen do svažitého terénu s jihovýchodní } \\
\text { orientací. }\end{array}$} & Zdroj KC & \multicolumn{2}{|c|}{ KS-PU } \\
\hline Autor & \multicolumn{7}{|c|}{ Ing. Tomáš Hudec, 777747 939, hudec.tomas@volny.cz } & GPS & \multicolumn{3}{|c|}{$49.1234567 \mathrm{~N}, 16.7654321 \mathrm{E}$} \\
\hline Foto uličr & pohled & & & Foto & např. ku & chyň) & & & Foto (např. kc & Ina) & \\
\hline
\end{tabular}




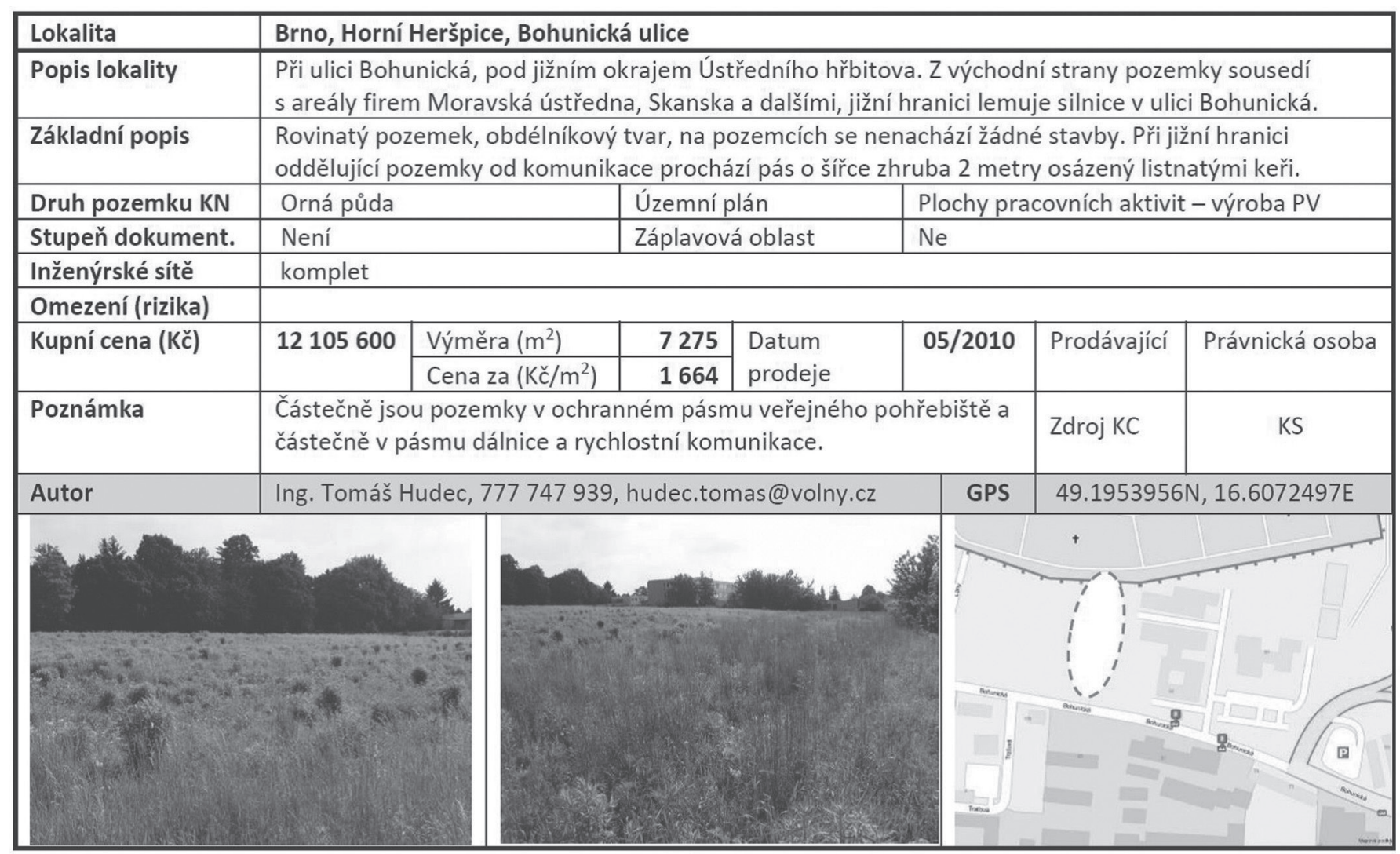

Obr. 3 Př́klad tabulky pro pozemky.

Fig. 3 Examples of a table for estate.

\section{Tabulka rodinné domy}

Lokalita: Pro lokalitu Brno-město a ostatní okresní města zápis ve tvaru: město, městská část, ulice. Pro ostatní lokality zápis ve tvaru: okres, obec, popřípadě ulice. Dále zde může být uvedený velmi stručný popis upřesňující specifika dané lokality, ve které se nemovitá věc nachází, např. výhled do parku, v těsné blízkosti základní školy, atd.

Podlaží: podzemní podlaži/počet nadzemních podlaží např. 1PP, 1NP.

Typ: např. 3+1, 2+KK.

Tech. stav: Rok dokončení výstavby, rok provedených rekonstrukcí apod., technické věci týkající se společných částí budovy, např. informace o zateplení fasády, stručná poznámka o údržbě, event. viditelné závady atd.

Zastavěná plocha RD $\left(\mathbf{m}^{2}\right)$ : plocha $\mathrm{v}$ metrech čtverečních zastavěné plochy 1 . NP.

Vybavení: stručný popis standardu vnitřního vybavení bytu, zejména způsob vytápění domu, zařizovací předměty apod.

Podlahová plocha celková $\left(\mathbf{m}^{2}\right)$ : Plocha v metrech čtverečních všech vnitřních prostor rodinného domu určených k bydlení, včetně vodorovného průmětu plochy schodiště - započitatelné pouze $1 \mathrm{x}$ a včetně vestavěné garáže a průjezdu (v obestavěném prostoru rodinného domu), včetně celého sklepa. Plocha místností se zkoseným stropem v celé ploše. Bez jakékoliv galerie, bez balkonu, lodžie, terasy.

Obestavěný prostor $\left(\mathrm{m}^{3}\right)$ : obestavěný prostor hlavní stavby v metrech krychlových stanovený dle př́lohy č. 1 oceňovací vyhlášky pro ceny zjištěné.
$\mathrm{Z}$ celkové p.p. plocha sklepa $\left(\mathrm{m}^{2}\right): \mathrm{Z}$ podlahové plochy celkové plocha sklepa (místností v suterénu netvorrící obytné místnosti).

$\mathbf{Z}$ celkové p.p. plocha garáže $\left(\mathbf{m}^{2}\right): Z$ celkové podlahové plochy plocha garáže vestavěné v obestavěném prostoru rodinného domu, nikoliv garáž jako samostatný objekt.

$Z$ celkové p.p. plocha průjezdu $\left(\mathbf{m}^{2}\right): Z$ celkové podlahové plochy plocha průjezdu.

Navíc p. p. balkon/lodžie/terasa $\left(\mathbf{m}^{2}\right)$ : Plocha balkonu, lodžie, terasy. Tato plocha není započítaná v podlahové ploše celkové. Započitatelná plocha dle ČBA $\left(\mathbf{m}^{2}\right)$ : Započitatelná plocha dle České bankovní asociace používaná v rámci odhadů pro úvěrová ř́zení.

Navíc p. p. galerie, ze které není vstup do dalších místností, min. sv.výška $1,7 \mathrm{~m},\left(\mathrm{~m}^{2}\right)$ :

Plocha galerie, která je součástí obestavěného prostoru samostatné místnosti. Tato plocha není započítaná v podlahové ploše celkové.

$Z$ celkové p.p. plocha místnosti se zkoseným stropem $\left(\mathrm{m}^{2}\right)$ : Rozděleno na dvě části:

1) Celková p. p. těchto místností $\left(\mathbf{m}^{2}\right)$ Celková plocha místnosti, bez ohledu na výšku tzv. nadezdívky a světlou výšku. 2) P. p. v části nad $1,3 \mathrm{~m},\left(\mathrm{~m}^{2}\right)$ :

Podlahová plocha pouze $\mathrm{v}$ té části místnosti, kde zkosený stropní plášt’ je minimálně 1,3 metru nad podlahou.

Pozemek: Plocha pozemku v metrech čtverečních. Pouze parcely stavebních pozemků užívaných ve funkčním celku s domem (zastavěné plochy, zahrady, ostatní plochy). Pokud 
$\mathrm{k}$ nemovité věci náleží např. $10000 \mathrm{~m}^{2}$ orné zemědělské půdy $\mathrm{v}$ jiné části obce a tato byla součásti prodeje, tak je tato skutečnost uvedena jen v poznámce.

Napojení na sítě: Zde jsou uvedeny všechny přípojky na veřejné sítě nebo vlastní zdroje. Uvádí se také např. možnost připojení $\mathrm{v}$ případě, že nemovitá věc není připojena na určitý typ sítě, avšak technicky je možné připojení provést.

Př́íslušenství: Stručný popis příslušenství jako jsou např. vedlejší stavby, zemní sklepy, garáže, studny apod.

Kupní cena: ověřená kupní cena bez ev. provize RK. Způsob ověření, viz buňka Zdroj KC.

Cena za $\mathbf{m}^{2}$ podlahové plochy (Kč): podíl kupní ceny a podlahové plochy celkové.

Datum prodeje: měsíc a rok, ve kterém byl prodej uskutečněný, tzn. datum uzavření kupní smlouvy.

Poznámka: To, co nelze zapsat do předchozích buněk a má dle úvahy odhadce vliv na uzavřenou kupní cenu nemovité věci.

Zdroj KC: Zdroj kupní ceny nebo ceny nájmu. Podle druhu předložené smlouvy je uvedená zkratka. KS - podepsaná kupní smlouva, KS-PU - kupní smlouva s vyznačenými právními účinky vkladu, KS-NV - kupní smlouva a návrh na vklad označený razítkem Katastrálního úřadu, BKS - smlouva o budoucí kupní smlouvě, RS - smlouva (dohoda) o rezervaci mezi potenciálním kupujícím a zprostředkovatelem, NS nájemní smlouva.

Autor: Zde je uvedený autor informací zobrazených v této tabulce a kontakt na něj. Tento údaj se v ocenění neuvádí, resp. je smazán. Slouží pouze pro zhotovitele ocenění v případě, že informace zde uvedené nejsou dle jeho názoru jednoznačné nebo dostačující. $V$ tom př́ípadě má možnost spojit se s autorem příslušné tabulky a požadované informace si ověřit, event. doplnit.

GPS: Upřesnění polohy nemovité věci v rámci Globálního polohového systému.

Fotografie: Fotografie budovy, výhledu z bytu do okolí a interiér se zaměřením na stavební konstrukce a stavební vybavení bytu jako jsou např. zařizovací předměty, podlahové krytiny, kotel apod.

\section{SOUČASNÝ STAV A VÝHLED NA NEJBLIŽŠÍ OBDOBÍ}

V současné době je databáze provozována již sedmým rokem na území Moravy, zejména v oblasti Jihomoravského kraje, Zlínského kraje a v části Kraje Vysočina. Podle typu nemovitých věcí je nejvyšší četnost zápisů o kupních cenách bytı̊. Na druhém místě jsou rodinné domy. $\mathrm{V}$ menší míř jsou ukládány zápisy o kupních cenách pozemků, rekreačních objektů, garáží a dalších typů nemovitých věcí včetně komerčních, a zápisy o cenách nájmů. Např́íklad za rok 2016 bylo uloženo do databáze 312 tabulek s kupními cenami bytových jednotek z lokality Brno-město a 178 tabulek s kupními cenami rodinných domů v lokalitě Jihomoravský kraj bez okresu Brno-město.

V každém roce přibývá přibližně deset nových uživatelů, kteří se stávají současně přispěvateli do databáze. V loňském roce byl tento nárůst vyšší, než v letech předchozích. Důvodem je výrazně nižší počet znaleckých posudků o ceně zjištěné zpracovávaných pro daňové účely. Znalci se ve své činnosti přeorientovávají více na posudky a odhady obvyklých cen, ve kterých využívají informace $\mathrm{z}$ databáze realizovaných cen prodaných a pronajímaných nemovitých věcech. Vzhledem $\mathrm{k}$ tomuto trendu lze očekávat, že v následující době bude pokračovat nárůst počtu uživatelů a informací o prodaných a pronajímaných nemovitých věcech.

\section{ZÁVĚR}

Externí databáze kupních cen nemovitých věcí a cen nájmů je pro znalce a odhadce jednou z možností jak si usnadnit a zefektivnit svoji práci při oceňování porovnávacím způsobem. Užívání výše popsané databáze je výhodné zejména $\mathrm{z}$ toho důvodu, že na uživatele neklade vysoké nároky na softwarové vybavení a znalost jeho užívání. Uživatelský komfort komunikačního prostředku se serverem formou správce souborů s nastaveným uživatelským účtem je poměrně vysoký a tzv. uživatelsky př́větivý. Grafická forma tabulek určených k zápisu informací o prodaných a pronajímaných nemovitých věcech je přehledná a natolik stručná, že provedení zápisu o jedné konkrétní nemovité věci netrvá déle než 2-3 minuty, přičemž tabulka obsahuje všechny potřebné popisné i číselné údaje, které mají vliv na porovnání $\mathrm{s}$ oceňovanou nemovitou věcí. Uložení tabulek v textovém editoru Word a současně ve formátu PDF umožňuje jejich snadný přenos do vytvářeného ocenění. V neposlední řadě je podstatnou výhodou tohoto systému jeho on-line způsob uživání tzn., že registrovaný uživatel může svoje data nahrát na server kdykoliv je to pro něj časově vyhovující. Tento systém umožňuje, aby databáze byla vždy aktuální a obsahovala tabulky od všech uživatelů přenesené do adresáře nemovitosti_data $\mathrm{v}$ horizontu několika dnů, po jejich uložení uživatelem do adresáře nemovitosti_sklad.

Uživatelem a přispěvatelem databáze se může stát každý znalec nebo odhadce, který splní podmínky uvedené v 3. odstavci tohoto článku. Roční uživatelský poplatek za užívání databáze je závislý na množství vložených tabulek a je postavený na principu „čím více vložím vlastních tabulek, tím méně zaplatím“. Podrobnější informace poskytne autor článku na vyžádání. V případě zájmu více potenciálních uživatelů z jednotlivých krajů České republiky je možné dohodnout provedení prezentace a praktickou ukázku užívání databáze (založení účtu s připojovacími údaji, připojení k serveru, stahování a ukládání informací apod.) v místě, dle zájmu potenciálních uživatelů. 